\title{
Acquiring Funds from NFEP\&WM by Religious Entities for Pro-environmental Activities
}

\author{
Artur Michalski \\ National Fund for Environmental Protection and Water Management \\ Konstruktorska 3A, 02-673 Warsaw, Poland \\ renata.gapanowicz@nfosigw.gov.pl
}

\begin{abstract}
Summary
Over the last 30 years, the National Fund for Environmental Protection and Water Management (NFEP\&WM) has been the main source of funding investments and other pro-ecological activities in Poland in the following areas: protection and sustainable management of water resources, support for projects in the scope of low-emission and resource-efficient economy, including innovation; waste management; earth surface protection, geology and mining; atmosphere protection, including improving air quality; biodiversity protection, environmental monitoring, counteracting environmental threats, ecological education, expertise and scientific and research works. Priority programmes implemented by the National Fund for Environmental Protection and Water Management supporting activities aimed at environmental protection, whose beneficiaries may be Church organizations include: Environmental Education, Protection of Biological and Landscape Diversity, Energy-saving Construction Part 1) Reduction of Energy Consumption in Construction.
\end{abstract}

\section{Keywords}

ecology, funding, environment, NFEP\&WM, Church

Over the last 30 years, the National Fund for Environmental Protection and Water Management (NFEP\&WM) has been the main source of funding investments and other pro-ecological activities in Poland. Having at its disposal the greatest financial potential, it provides a rich offer tailored to the expectations of a wide range of beneficiaries: local governments, enterprises, public entities, social organizations and individuals. In the public finance sector, the National Fund is also the largest partner, in Poland, of international financial institutions in handling foreign funds allocated for environmental protection (Phare/EFP Phare 1990-2003, NEFCO, GEF, ISPA 1993-2003, UE Cohesion Fund 2000-206, SOP-WKP 2005-2009, Programme LIFE+ 2008-2013, SIDA 1990-2014, NFM 2009-2014, MF EEA 2004-2009, 2007-2013 and 2014-2020 Infrastructure and Environment Operational Programme, Programme LIFE 2014-2020).

The current level of funding for environmental protection is about PLN 5 billion a year, including approx. $50 \%$ from EU and national funds. Priority 
activities include: water and air protection, preservation of biodiversity, adaptation to climate change, as well as geology, mining and circular economy. Areas financed by the NFEP\&WM include: protection and sustainable management of water resources, support for projects in the field of low-carbon and resource-efficient economy, including innovation; waste management; earth surface protection, geology and mining; atmosphere protection, including improving air quality; biodiversity protection, environmental monitoring, counteracting environmental threats, ecological education, expertise and scientific and research works. The National Fund offers beneficiaries assistance in efficient and timely implementation of projects. It provides financial support primarily for projects fulfilling Poland's environmental commitments arising from EU membership. It also supports the activities of the Minister for the Environment in fulfilling Polish obligations under, inter alia, the Climate Convention, the Convention on Biological Diversity, the NATURA 2000 programme and other international agreements and arrangements.

Priority programmes implemented by the National Fund for Environmental Protection and Water Management, supporting activities aimed at environmental protection, whose beneficiaries may be Church organizations include: Environmental Education, Protection of Biological and Landscape Diversity, Energy-saving Construction Part 1) Reduction of Energy Consumption in Construction.

The Ecological Education priority programme envisages earmarking PLN 200 million in the form of subsidies and PLN 10 million in the form of loans from national funds in the years 2015-2023 for the purposes of broadly understood ecological education. Under the programme, commitments will be made until 2020, while project implementation and spending are foreseen by 2023 .
Under this programme, the National Fund co-finances the implementation of media campaigns, films, cyclical radio and television programmes, press publications, programmes for active public education for sustainable development, construction, expansion, renovation, adaptation, equipping and retrofitting of ecological education centres, completion of postgraduate studies on environmental protection, production of teaching aids, organization of trainings, conferences, seminars, workshops, competitions and other events disseminating ecological knowledge. Preference will be given to projects tailored to the specifics of the target group to which they are addressed, activating participants of educational activities and based on the latest technologies.

The abovementioned programme provides co-financing for: non-governmental organizations (foundations, associations), national parks, local government units, companies (sole proprietorships, companies), universities, Church organizations and religious associations. Projects having supra-regional or national scope will be co-financed in the form of a subsidy and a possible loan to cover the own contribution.

Four funding thresholds have been envisaged, depending on the legal personality of the applicant, namely:

1. up to $100 \%$ of eligible costs for national parks;

2. up to $95 \%$ of eligible costs for entities that have submitted applications for co-financing projects of particular importance for implementing the policy of the Minister responsible for the environment;

3. up to $90 \%$ of eligible costs for entities having the status of non-governmental organizations, in accordance with Article 3 Section 2 of the Act on Public Benefit and Volunteer Work and units of the public finance sector other than State budget units and national parks;

4. up to $70 \%$ of eligible costs for other entities. 
An example of a successful educational project is the National Programme for Active Education: "Young people for the environment” (Ogólnopolski Program Aktywnej Edukacji - "Młodzi dla środowiska") run by the Catholic Youth Association of the Drohiczyn Diocese (Katolickie Stowarzyszenie Młodzieży Diecezji Drohiczyńskiej). A number of off-site training and workshops for young people, combined with exploring the most beautiful parts of our country, were carried out from $31 \mathrm{March}, 2017$ to 31 December, 2018 (https://www.mlodzidlasrodowiska.pl). The total cost of implementing this project is: PLN 3,737,033.00, of which PLN 3,550,178.08 was co-financed by the National Fund for Environmental Protection and Water Management. Another example is the "Postgraduate studies: Environmental monitoring and mediation in ecological conflicts" project implemented by the Cardinal Stefan Wyszynski University in Warsaw (www.ekologia.uksw.edu.pl). The project implemented from 1 November, 2016 to $31 \mathrm{March}, 2019$ received a grant of PLN $291,953.00$. The cost of the entire project is PLN 333,024.0o. These undertakings provide an important example of the involvement of Church organizations in activities of various social groups for environmental awareness and education in this field.

The priority programme "Protection of Biological and Landscape Diversity", involves halting the loss of biological and landscape diversity, restoring and enriching nature resources, and effective management of species and habitats. PLN 162 million was earmarked for this purpose, of which PLN 136 million in the form of subsidies.

As can be proven by the history of Poland, the Church for many centuries created in the vicinity of sacred buildings parks, gardens and monastery farms that implemented the principles of modern management of environmental resources. The fact that many of these objects have survived to this day, provides evidence for their balanced way of functioning. They all bear witness to history, but many of them have lost their value and require support to be restored to the Polish culture.

NFEP\&WM under the priority programme 4.1 "Protection of nature and restoration of biological and landscape diversity part 1) Protection of areas and species valuable for nature" provides support for activities related to the maintenance and preservation of parks and gardens, which are objects of protection under the provisions on the protection of monuments and the care of monuments as well as those related to nature protection.

The basic eligibility condition for obtaining funding for projects related to the maintenance and preservation of historic parks and gardens is the entry in the register of monuments and project's approval by the Provincial Conservator of Monuments. Entry in the register of monuments can be made at the request of the facility's owner. The beneficiary of this aid may be entities that are the owner, perpetual usufructuary or manager of historic parks and gardens. An additional condition is that historic parks and gardens benefiting from the support of the NFEP\&WM must be open to public.

A very valuable aspect here is the commitment of those benefiting from the support of Church institutions to take active part in shaping the ecological sensitivity of our society and promoting concern for the natural environment by organizing symposia, lectures, permanent exhibitions and publishing brochures on environmental care. The programme envisages additional 5 points for the abovementioned actions in the assessment of the project under the Environmental Education Component.

Examples of using the funds provided under this programme are such projects as: "Protection of the historic park complex at the Roman Catholic Parish of St. Anne in Kodyn', where the costs of carrying out protection activities of the historic park amounted to PLN 404,615.00, of which PLN 364,153 . oo was co-financed by the National Fund for Environmental Protection and Water Management, or "Revalorization 
of the monastery park at the Salvatorian Monastic House in Bagno - restoration of the utility garden, restoration to its original the state of the water reservoir and planting ecotone zones" carried out by the Salvatorian Major Seminary in Bagno in 2012-2013. As part of this project, the revaluation of the historic park amounted to PLN 1,432,216.00, of which PLN 1,153,792.00 was co-financed by the NFEP\&WM. Other examples of funding under the programme include the following projects: "Revalorization of historic canonical gardens in Frombork - stage I - restoration of the regular arrangement of vegetation" implemented by the Warmian Cathedral Chapter in Frombork in 2013-2014, where the renovation of historic gardens cost PLN $532,178.00$, of which PLN 447,470.00 was cofinanced by the NFEP\&WM and a project entitled "Restoration of landscape resources in the historic park in Huta Komorowska through the revitalization of greenery" implemented by the Sandomierz Diocese in 2013-2014. A similar project has been implemented since 11 February, 2016 by the Benedictine Abbey in Lubin. It includes "Care and protection works on the historic stand of the Benedictine Abbey in Lubin Historical Monument". Under the contract with the Abbey, NFEP\&WM will provide subsidies in the amount of PLN 536,727.00 from total costs planned at PLN 596,364.00. The project will be completed on 30.11.2019. The listed projects importantly combine the issues related to protecting objects of high cultural, historical, but also pre-eminently those of natural value.

Under the Priority Programme Energysaving Construction Part 1) Reduction of Energy Consumption in Construction, the funding may be obtained by:

- $\quad$ entities conducting medical activity in the field of stationary and roundthe-clock health services in the form of, in particular, hospitals, care and treatment facilities, care and nursing facilities, hospices, entered in the register of entities conducting healthcare activities;

- $\quad$ entities operating museums entered in the State Register of Museums;

- $\quad$ entities operating student dormitories;

- entities owning a historic building entered in the Register of Historic Monuments or in the provincial or municipal records, in accordance with the Act of July 23, 2003 on the protection of monuments and care for historical monuments;

- legal persons or religious associations within the meaning of separate provisions of the Act on the relationship of the State to other churches and religious associations and on guarantees of freedom of conscience and religion, as well as associations and foundations established by these entities.

Energy modernization concerns the following types of buildings:

- hospitals, care and treatment facilities, care and nursing facilities, hospices;

- historic buildings, i.e. those that have been entered in the Register of Historic Monuments or are in the voivodship or commune register, in accordance with the Act of July 23, 2003 on the protection of monuments and care for historical monuments;

- religious buildings;

- accompanying buildings as defined in the Act of 17 May 1989 on the attitude of the State to the Catholic Church in the Republic of Poland and administrative and economic buildings, as well as collective residence buildings related to religious worship (monasteries, retreat houses, pilgrim's houses);

- $\quad$ student dormitories;

- other buildings intended for the purposes of culture, religious worship, education, care, upbringing, education.

Co-financing obtained under the abovementioned programme can be used for: insulation of the object (including walls, slab-on-grade floors, floors, flat 
roofs and other partitions, replacement of windows, replacement of external doors, reconstruction of heating systems (including replacement of a heat source, including a renewable energy source), replacement or installation of ventilation and air conditioning systems, the use of energy management systems in buildings, the use of renewable energy sources, preparation of technical documentation, including functional and utility programmes, technical expertise, energy audits (energy efficiency audits), mycological expertise, elimination of moisture and its effects in an energymodernized building, replacement of indoor and outdoor lighting for energy-efficient buildings and replacement of roofing.

The intensity of co-financing depends on the number of improvements applied:

- thermo-modernization works (i.e. improvements consisting in improvement of thermal insulation of partitions and modernization/execution of heating installations, hot utility water, ventilation, air conditioning and electric);

- the use of renewable energy sources (RES);

- application of energy management systems.

The grant intensity may amount up to a maximum of:
- $85 \%$ of eligible costs in case of applying one of the mentioned types of improvements;

- $\quad 90 \%$ of eligible costs if two of the following types of improvement are applied;

- $\quad 95 \%$ of eligible costs if all (three) types of improvement are applied;

- the loan may be up to $100 \%$ of eligible costs, while the sum of repayable (loan) and non-repayable (grant) financing may not exceed $100 \%$ of eligible costs;

- $\quad$ in order to obtain support including both a grant and a loan, it is necessary to submit two separate applications (grant and loan).

Co-financing may be granted for an undertaking which has been commenced (with the provision that it was commenced after 01.01.2016) but has not been completed (i.e. received based on the final acceptance protocol) before the day of submitting the application for co-financing. The minimum eligible cost of the undertaking above PLN 100,00o. It is allowed to reduce the amount of the eligible project cost below PLN 100,000 after submitting the application for co-financing, if it occurred as a result of the procedures related to the award of the works contract.

\section{Pozyskiwanie funduszy z NFOŚiGW przez podmioty religijne na rzecz działań prośrodowiskowych}

\section{Streszczenie}

Narodowy Fundusz Ochrony Środowiska i Gospodarki Wodnej (NFOŚiGW) od 30 lat jest głównym źródłem finansowania inwestycji i innych działań proekologicznych w Polsce w następujących obszarach: Ochrona i zrównoważone gospodarowanie zasobami wodnymi, wsparcie przedsięwzięć w zakresie niskoemisyjnej i zasobooszczędnej gospodarki, w tym innowacji; gospodarka odpadami; ochrona powierzchni ziemi, geologia i górnictwo; ochrona atmosfery, w tym poprawa jakości powietrza; ochrona różnorodności biologicznej, monitoring środowiska, przeciwdziałanie zagrożeniom środowiska, edukacja ekologiczna, ekspertyzy i prace naukowo-badawcze. Wdrażane przez NFOŚiGW programy priorytetowe, wspierające działania służące ochronie środowiska, których beneficjentami mogą być organizacje kościelne to między innymi: Edukacja ekologiczna, Ochrona różnorodności biologicznej i krajobrazowej, Budownictwo energooszczędne Część 1) Zmniejszenie zużycia energii w budownictwie. 


\section{Slowa kluczowe}

ekologia, finansowanie, środowisko, NFOŚiGW, Kościół

\section{Nota 0 autorze}

ARTUR MICHALSKI - od grudnia 2015 r. Zastępca Prezesa Zarządu Narodowego Funduszu Ochrony Środowiska i Gospodarki Wodnej. Poprzednio pełnił tę funkcję w latach 2006-2008. Jest absolwentem Wydziału Elektrycznego Politechniki Częstochowskiej. Ukończył specjalistyczne studia podyplomowe: Studium Oceny i Wyceny Zasobów Przyrodniczych SGGW i SGH, Kompensacje Przyrodnicze Natura 2000 (SGGW), Polityka Ochrony Środowiska - Ekologia i zarządzanie. Uczestniczy w badaniach prowadzonych przez Pracownię Oceny i Wyceny Zasobów Przyrodniczych (SGGW). Jest autorem lub współautorem kilkunastu publikacji naukowych.

\section{Author's note}

ARTUR MICHALSKI - since December 2015, Deputy President of the Management Board of the National Fund for Environmental Protection and Water Management; he previously held this function in the years 2006-2008. Graduate of the Faculty of Electrical Engineering of the Czestochowa University of Technology. He completed specialist post-graduate studies: Study of Assessment and Valuation of Natural Resources at the Warsaw University of Life Sciences (SGGW) and the Warsaw School of Economics (SGH), Nature Compensation Natura 2000 (SGGW), Environmental Protection Policy - Ecology and management. Michalski participates in research conducted by the Laboratory of Assessment and Valuation of Natural Resources (SGGW); author or co-author of over a dozen scientific publications. 